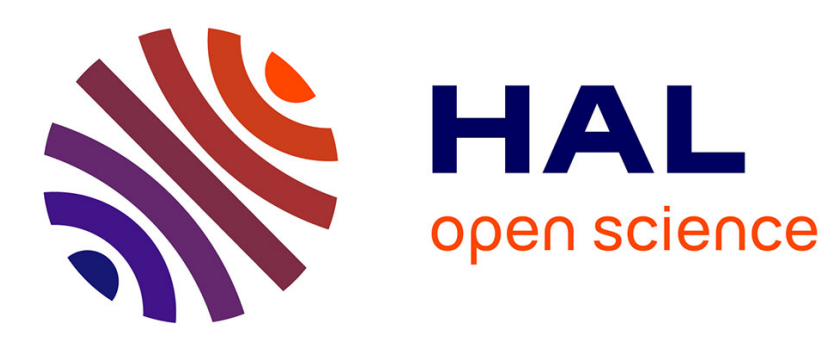

\title{
Diversity and dynamics of eco-units in the biological reserves of the Fontainebleau forest (France): contribution of soil biology to a functional approach
}

Pierre Arpin, Jean-François Ponge, André Faille, Patrick Blandin

\section{- To cite this version:}

Pierre Arpin, Jean-François Ponge, André Faille, Patrick Blandin. Diversity and dynamics of ecounits in the biological reserves of the Fontainebleau forest (France): contribution of soil biology to a functional approach. European Journal of Soil Biology, 1998, 34 (4), pp.167-177. 10.1016/S11645563(00)86659-5. hal-00505367

\section{HAL Id: hal-00505367 https://hal.science/hal-00505367}

Submitted on 25 Aug 2010

HAL is a multi-disciplinary open access archive for the deposit and dissemination of scientific research documents, whether they are published or not. The documents may come from teaching and research institutions in France or abroad, or from public or private research centers.
L'archive ouverte pluridisciplinaire HAL, est destinée au dépôt et à la diffusion de documents scientifiques de niveau recherche, publiés ou non, émanant des établissements d'enseignement et de recherche français ou étrangers, des laboratoires publics ou privés. 


\title{
Diversity and dynamics of eco-units in the biological reserves of the Fontainebleau forest (France): Contribution of soil biology to a functional $\operatorname{approach}^{\S}$
}

Pierre Arpin $^{\mathrm{a} *}$, Jean-Franqois Ponge ${ }^{\mathrm{a}}$, Andre Faille ${ }^{\mathrm{b}}$, Patrick Blandin ${ }^{\mathrm{c}}$

a Muséum national d'histoire naturelle, Écologie générale, 4, avenue du Petit-Château, 91800 Brunoy, France.

${ }^{\mathrm{b}}$ Laboratoire de biologie végétale et d'écologie forestière, université Paris-VII, route de la Tour-Dénecourt, 77000 Fontainebleau, France.

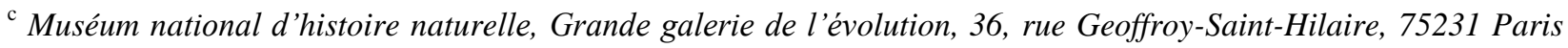
cedex 05, France.

*Corresponding author (fax: +33 1604657 19; e-mail:ar@n@mnhn.fr)

\begin{abstract}
Beech integral biological reserves of the Fontainebleau forest (France) display varied site conditions due to geomorphological heterogeneity and to interactions between biological components of the ecosystem. Taking examples in shifts observed in plant communities following gap opening, the authors show that, as Oldeman viewed it, tree-fall gaps seem to be the driving force in sylvigenesis as well as a source of spatial biodiversity. Studies carried out on macromorphological features of humus profiles and on the behaviour of soil invertebrate communities (Lumbricidae and Nematoda) pointed out two key aspects of forest functioning. First, the renewal of the forest ecosystem is linked to the dynamics of humus forms and of soil animal functional groups, featuring the regeneration of trees. Second, tree-fall gaps are places where the forest ecosystem is destabilized and thereafter may renew itself
\end{abstract}

\footnotetext{
$\S$ Part of this synthesis has been presented at the International Congress on 'Naturalness and European forests' (Strasbourg, France, 26-29 October 1997) under the title 'Dynamics of eco-units in the Fontainebleau forest biological reserves. The role of chablis and consequences for biodiversity'
} 
or on the contrary may evolve towards another ecosystem, showing either a co-adaptation between the sylvigenetic and the edaphic cycle, or a discordance between these two cycles. These two aspects (co-adaptation and discordance), important from the point of view of fundamental ecology and forest management, suggest a need for further field research.

Sylvigenetic cycle / humus dynamics / biodiversity / soil biology / Lumbricidae / Nematoda / beech grove / ecosystem functioning

Résumé - Diversité et dynamique des éco-unités dans les réserves biologiques de la forêt de Fontainebleau (France) : apports de la biologie des sols à une approche fonctionnelle. La hêtraie des réserves biologiques intégrales de la forêt de Fontainebleau offre des situations naturelles variées en fonction de l'hétérogénéité géomorphologique et des interactions entre les composantes biologiques de l'écosystème. Prenant comme exemple l'évolution des associations végétales au sein des clairières, les auteurs montrent que, selon la conception d'Oldeman, le chablis apparait comme l'élément moteur de la sylvigénèse et un facteur important de biodiversité spatiale. Des études portant sur la caractérisation macromorphologique des profils d'humus et le comportement des peuplements d'invertébrés du sol (Lumbricidae, Nematoda) mettent en avant deux points importants pour le fonctionnement de l'écosystème forestier. Premièrement, le renouvellement de l'écosystème est associé à la dynamique des humus et des groupes fonctionnels de la pédofaune, façonnant ainsi la niche de régénération. Deuxièmement, les clairières apparaissent comme une zone de rupture de l'écosystème forestier pouvant lui permettre, soit de se renouveler, soit d'évoluer vers un autre écosystème, montrant ainsi soit une co-adaptation entre le cycle sylvigénétique et le cycle édaphique, soit une discordance entre ces deux cycles. Cette approche fonctionnelle, par le biais de la biologie des sols suggère une réflexion touchant autant l'écologie fondamentale que la gestion forestière.

Cycle sylvigénétique / dynamique des humus / biodiversité / biologie du sol / Lumbricidae / Nematoda / hêtraie / fonctionnement de l'écosystème 


\section{INTRODUCTION}

The interest of biological reserves for the functioning and dynamics of forest ecosystems has been underlined time and again $[19,24,25,36,46,52]$. In the absence of management, such ecosystems show a patchwork of developmental phases called eco-units by Oldeman [36]. The influence of site heterogeneity crosses that of time sequences, increasing their global diversity $[8,17,39]$. Biological reserves are indispensable to a good understanding of nature conservation or sustainable management of forests $[9,11,20,48]$. In addition, their study may be of interest to foresters. Answers to debated questions, such as regeneration failure, search for minimal cost production and greenhouse effect, can be found in the study of these untouched ecosystems. For instance, the growth of trees in the absence of thinning operations, the natural regeneration of late-successional tree species, may indicate what could be the fate of a forest ecosystem without sylvicultural practices. It is supposed to be useful to new management practices, taking into account ecological interactions, ensuring long-term stability of the ecosystem at the lowest cost.

For about 30 years, extensive scientific research has been carried out in 'La Tillaie' and 'Le Gros Fouteau' areas of the Fontainebleau state forest (France). These two parcels are classified as integral biological reserves, which means that management has been abandoned for more than three centuries, a unique situation within lowland forests of western Europe. Research effort has focused especially on the life history of trees, vegetation dynamics, plant sociology, soil science, bio- geochemical cycles and on the impact of small mammals and birds on predation and dispersal of seeds $[10,15,27,29,43,44]$. Studies on biological properties and functioning of humus profiles in relation to the sylvigenetic cycle started just a few years ago, sponsored by the French National Office of Forests and the French Ministry of the Environment [1, 3, 14, 39, 42].

Although limited in area, the beech stands of 'La Tillaie' (36 ha) and 'Le Gros Fouteau' (25 ha) offer a variety of situations due to the heterogeneous deposition of Fontainebleau sand and to interactions between biological components of the ecosystem. These changing site conditions influence the distribution of plant life forms as well as of humus forms and the structure of soil animal communities, as will be seen below. Making references to previous works, this paper presents a synthesis of recently published research results [1, 3, 14, 39, 44]. It suggests a multifunctional approach of the ecosystem dynamics highlighting:

1) The role of tree-fall gaps as starting events and driving forces in sylvigenetic cycles, generating spatial diversity in the ecosystem; 
2) The influence of forest dynamics and external factors on the observed diversity; 3) The relation between soil fauna and ensuring soil properties on the renewal of the ecosystem;

3) The need for new ideas on biodiversity and forest management.

\section{GAPS AND FOREST DYNAMICS}

Tree-fall gaps, often caused by storms, seem to be the driving force in sylvigenesis as well as a source of plant biodiversity [44]. Pontailler et al. [44] analysed the consequences of storms in 1966 and 1967 until that of 1990 which created gaps of varying size in the biological reserves of the Fontainebleau forest. In 'La Tillaie' (34.15 ha prospected), the surface of gaps amounted to 2.56 ha (168 trees) and 2.70 ha (153 trees), for 1967 and 1990 storms, respectively. In 'Le Gros Fouteau' (23 ha prospected), the areas affected by these storms amounted to 1.05 ha (60 trees) and 4.81 ha (493 trees), respectively. Between these two violent events, 198 dead trees were reported in 'La Tillaie', $20 \%$ of them still standing (surface of gaps: 1.15 ha).

According to Oldeman's nomenclature [36], each gap opening constitutes the 'zero event' of a given ecounit. It is the beginning of an internal dynamics of the ecosystem which leads gradually, in a variety of ways, to the closure of the canopy and later phases of growth (growth or aggradation phase), maturing (mature or full-grown phase or biostasis), then senescence, collapse and tree decay. Changes in the surface area of gaps over time and according to various events illustrate this dynamic process. Thus, at 'La Tillaie', gaps amounted to $7 \%$ of the total surface area before the storms in 1966-1967 (figure 1). Thereafter, they reached $15 \%$. The gap area then decreased and was only $4 \%$ in 1981. At this date, gaps occurring in the period 1967-1981 (133 tree-falls) were only $2.5 \%$. In 1989, despite 65 new accidents, the total gap area was $3 \%$ only (among which $0.8 \%$ corresponded to old gaps), and increased to $13 \%$ after storms in 1990. A quite similar evolution took place in 'Le Gros Fouteau' [44]. Analysing the frequency of new gaps during the periods 1967-1981 and 1981-1990, Pontailler et al. [44] concluded that the natural beech ecosystem had reached a steady state characterized by a more or less constant $2.5 \%$ opening rate (due to natural mortality and uprooted or broken trees). Such a dynamics resulted in the development, in space and time, of a mosaic of eco-units, the diversity of which will be explained below. 


\section{DIVERSITY OF ECO-UNITS}

The thickness of the wind-blown Fontainebleau sand layer as well as the presence or absence of an underlying limestone layer are important geomorphological features explaining the heterogeneity of forest dynamics. They affect various plant and soil animal communities, humus forms and, lastly, the regeneration potential of beech.

In the case of 'La Tillaie', maps of soil types $[10,15]$ show in the western part of the area a zone called 'plateau', covered with a thin layer of Fontainebleau sand (between 50 to $100 \mathrm{~cm}$ ) overlying a continuous limestone table, where soils are mostly acid-leached soils (= dystric cambisols according to Unesco-FAO classification [16]). In the eastern part, there is a zone called 'sandhill', with podsolic soils developed in a 1-2-m thick layer of sand overlying a solid limestone bedrock. In the northern part, there is a zone called 'sandstone', with sandstone outcroppings covered with Fontainebleau sand, without limestone, the soils being of the neopodsolic or podsolic type, temporarily water-logged.

Studies on humus forms gave important information on this area. Results from correspondence analyses of morphological features [39] on thirty plots covering all the situations (geomorphology and forest dynamics) showed three groups of humus forms associated with geomorphological types. The 'plateau' zone presented mainly acid mull humus forms characterized by the absence of an $\mathrm{OH}$ horizon and the presence of a thin light yellow A horizon. Contrary to expectation, the 'sandhill' zone presented a mull-like moder humus form characterized by the absence of an $\mathrm{OH}$ horizon but with a deep dark yellow A horizon. The 'sandstone' zone presented moder to dysmoder humus forms characterized by the presence of an $\mathrm{OH}$ horizon and a dark reddish A horizon. These latter features prevailed especially in clearings covered with a continuous layer of bracken (Pteridium aquilinum (L.) Kuhn.) where the absence of regeneration of beech and a standby in the sylvigenetic cycle were observed [14].

\section{GEOMORPHOLOG.Y, GAPS AND THE PLANT COMMUNITIES}

\subsection{Forest phytosociological groups}

Three phytosociological groups have been recognized [25], according to soil types. Herbaceous beech stands of the Fagetalia (Fagus silvatica L.) were present on leached acidic soils, beech stands with Ilex aquifolium (L.) and a few sessile oaks (Quercus petraea Liebl.) belonging to Quercetalia rubori-petraeae on podsol, podsolic 
and neopodsolic soils, and an intermediate group with both acidophilic species of the Quercetalia and neutrophilic species of the Fagetalia here and there.

The influence of gaps then comes into play. Adding itself to geomorphological and soil diversity, the intensity of light, which depends on the size of gaps, induces greater development and diversity of the herbaceous layer in clearings compared to close stands [17]. In particular, within the above-mentioned plant communities, Faille [17] identified five floristic groups, so that different groups of clearings could derive from the same forest plant community. Thus, groups $\mathrm{A}$ and $\mathrm{B}$ corresponded to the most demanding species, with for A, the presence of neutrophilic species absent from nearby stands, forest grasses and young trees such as ash, maple, and blackthorn. Groups D and E were characterized by the presence of acidophilic species (Carex pilulifera L., Pteridium aquilinum) and sessile oak seedlings, with for E the disappearance of Euphorbia amygdaloides L. and Anemone nemorosa L. and the presence of mosses (Dicranella heteromalla (Hedw.) Schimp., Leucobryum glaucum (Hedw.) Angstr., Hypnum cupressiforme Hedw.). Group C was intermediate, including the most common grasses of the Fagetalia except the most demanding species of group A and the most acidophilic species of group E.

\subsection{Social heliophytes}

Often, in the absence of early regeneration of beech, clearings evolve in a way that is characterized by the establishment and the development of social heliophytes; thus, the same clearing plant community may present different modalities [17]. P aquilinum was found growing on nearly all soil types, but developed particularly well on sandstone. Calamagrostis epigeios (L.), which is rather tolerant to soil acidity, appeared to grow less on podsols. Rubus fruticosus L. was especially abundant on leached acidic soils. The rarer Brachypodium pinnatum (L.) Beauv. was found on the shallowest leached acidic soils. When these social species fully invade a clearing, they may slow down the regeneration of trees to varying degrees, especially C. epigeios, the litter of which forms a thick mulch. Nevertheless, the clearings finally were closed according to different strategies [18]: (i) crown enlargement of trees located at the edge of clearings; (ii) stimulated crown development of pre-existent dominated (young) trees; and (iii) establishment of seedlings following ageing and collapse of the heliophyte populations. Thus, in 'La Tillaie', bracken ( $P$. aquilinum), that covered nearly 5 ha in 1972, covered only 0.5 ha 10 years later. Over the same period of time, the area covered by $C$. epigeios decreased to 0.6 ha, then to $700 \mathrm{~m}^{2}$, and today reaches only $40 \mathrm{~m}^{2}$. Exceptions 
are clearings covered by a dense layer of bracken on sandstone, because of the poor development of nearby beech trees, the crowns of which cannot enlarge enough to fill the gaps and shade the fern.

\subsection{Shade-intolerant trees}

Another interesting feature of the diversity brought about by clearings is the fact that shade-intolerant trees may establish themselves and grow in the largest clearings [28]. A few old gaps were closed by individuals of Pinus sylvestris L. (no longer present), Betula pendula Roth, Quercus petraea (Mattus.) Liebl. and Fraxinus excelsior L. For their successful establishment and survival, these opportunistic species are given only a limited lapse of time to escape competing grasses (social heliophytes) and regenerating beech. This lapse of time varies greatly, depending upon the rate of colonization of the ground vegetation. The settlement time amounts approximately to 12 years for birch and to 20 years for oak. By contrast, ash trees fully occupied within 3 years a clearing opened in 1965 at the edge of 'La Tillaie'. Nonetheless, after this phase of establishment, competition with shade-tolerant species such as beech or hornbeam takes place in a variety of ways: crown enlargement of shade-tolerant trees located at the periphery of clearings, competition with roots of shade-tolerant species for water and nutrients, and competition for space and light with the crowns of other trees when individuals reach the same height, or are dominated by them [18]. This explains how all isolated Scots pine trees were eliminated by beech or hornbeam.

\section{HUMUS FORM, FOREST DYNAMICS AND REGENERATION OF BEECH}

If we focus on the regeneration of beech, we can note the prominent influence of geomorphology on sylvigenesis by the intermediary of humus forms. A study carried out in 'La Tillaie' [51] on forty selected plots embracing all geomorphological types and stages of the forest cycle, revealed that the 'plateau' zone with a leached acidic soil and an acid mull humus form was the most favourable zone for the survival of 1-year-old seedlings, the highest mortality rate during the dry summer of 1996 reaching $60 \%$ in the 'sand-hill' zone with mull-moder humus (figure 2). Comparing means by r-test revealed significant differences at 0.01 threshold level for 'plateau' versus 'sandhill' $(\mathrm{t}=33.48)$ or 'plateau' versus 'sandstone' $(\mathrm{t}=13.19)$ but no significant differences for 'sandhill' versus 'sandstone' $(\mathrm{t}=2.80)$. The importance of humus form improvement (transition from moder to mull) for the success 
of beech regeneration has been emphasized by several authors [31, 36, 37, 54]. Moreover, the influence of forest stages on seedling survival rate was also shown. It was highest in the early mature stand, significantly higher (at 0.01 threshold level) than that in gap + senescent phase $(t=7.39)$. The latter was significantly higher than those in growth phase $(t=13.68)$ and late mature stand $(t=4.01)$ which were not significantly different from one another.

\section{GEOMORPHOLOGY, FOREST DYNAMICS AND EARTHWORM POPULATIONS}

\subsection{Geomorphology, earthworms and humus}

A study of earthworm communities (thirty sites, randomly chosen, encompassing a range of soil and vegetation conditions) showed that ecological categories of earthworms were particularly influenced by the thickness of the sand layer and the presence of limestone and produced specific morphological features of the humus profiles $[14,39]$. Analysis of variance according to geomorphology with morphological measurements of humus profiles and earthworm density and biomass [39] as dependent variables showed that earthworm communities differed significantly between the three geomorphological situations (see section 3, sand on limestone, shallow; sand on limestone, deep; sand on sandstone). Anecic and endogeic worms were found especially in leached acidic soils of the 'plateau' zone (sand on limestone, shallow) with an acid mull humus form where they made up the bulk of the population, in terms both of total densities (respectively 146, 34 and 20 ind $\cdot \mathrm{m}^{-2}$ in the 'plateau', 'sandhill' and 'sandstone' zones) and biomasses (52, 16 and $5 \mathrm{~g} \cdot \mathrm{m}^{-2}$, respectively). Epigeic worms, linked to the litter habitat, were dominant in podsols of the 'sandhill' zone (sand on limestone, deep) with mull-like moder humus form and made up the bulk of the population in neo-podsolic and podsolic soils of the 'sandstone' zone with moder to dysmoder humus forms (respectively 194 and 142 ind $\cdot \mathrm{m}^{-2}$ for densities and 14 and $23 \mathrm{~g} \cdot \mathrm{m}^{-2}$ for biomasses, respectively). In the 'plateau' zone, densities and biomasses of epigeic earthworms were $130 \mathrm{ind} \cdot \mathrm{m}^{-2}$ and $12 \mathrm{~g} \cdot \mathrm{m}^{-2}$ respectively. The 'sandstone' zone showed a low diversity of species with only one epigeic species, Lumbricus castaneus (Savigny, 1826). These results seem to reveal the influence of geomorphology on the distribution of earthworm ecological categories. Some indication of causal events which explain this phenomenon can be gained from the study of the mineral composition of beech litter. When the limestone table is present in a weathered form ('plateau' zone), then beech litter becomes richer in calcium, which fulfil nutrient requirements of saprophagous macrofauna [42]. These animals in turn, by their activities, modify the humus profile. Particularly, the absence of lime, the seasonal water- 
logging of the sandstone table and the ensuing absence of burrowing earthworms brought about the formation of an ectorganic $\mathrm{OH}$ horizon characterizing moder and dysmoder humus forms. In the same way, the acid mull humus form of the 'plateau' zone is due to the presence of a full earthworm community, notably with anecic and endogeic species, which incorporate litter to underlying mineral horizons. The mull-like moder humus form in the 'sandhill' zone, where earthworm communities were dominated by epigeic species and the presence of a small anecic population, can be explained by a slower burying of litter within a dark organo-mineral horizon where organic matter is probably further mineralized at a lower rate than in acid mull [26].

\subsection{Forest dynamics and earthworms}

Analysis of variance according to phases of the forest cycle (mature or full-grown stage or biostasis, treefall gaps or clearing, growth phase or aggradation) with measurements of humus profiles and earthworm density and biomass as dependent variables showed that the structure of earthworm communities changed significantly according to forest dynamics [39]. The influence of the sylvigenetic cycle of the beech ecosystem on the populations was tested in the 'plateau' zone only. Endogeic and anecic species being abundant only in mature beech stands, the density of anecic earthworms was observed to decrease abruptly in recent gaps and to remain low during the growth phase, together with a collapse in endogeic populations (figure 3). Epigeic species were the bulk of the population at sites in a growing phase. This could be explained by the abrupt decrease in litter input following death of trees in recent gaps, followed by an accumulation of organic matter above the soil surface during the growth phase [39]. If we consider the low litter-fall input in gaps, we can compare these results with experimental effects of litter deprivation on a similar humus type [12] where a sharp decline in earthworm populations, mainly soil-dwelling species, was observed. Moreover, in the same experimental work, an increase in litter-fall simulating a growth phase was not followed by an increase in litter-feeding earthworm populations. Ponge and Delhaye [39] thought that a positive increase in food resources might be counter- balanced by negative effects such as impoverishment and acidification of mineral horizons in relation to nutrient cycles in tree plantations. The uptake of nutrients by trees in the soil might decrease once growth has ceased as previously reported $[8,38,41]$.

These results seemed to indicate that beech of the 'plateau' zone growing on leached acidic soils with acid mull humus provided a good model for a deeper analysis of the relationships between the sylvigenetic cycle and the 
edaphic biological system.

\section{FOREST DYNAMICS AND HUMUS FORM CHANGES}

Macromorphological features of humus profiles change along with the sylvigenetic cycle and, as mentioned above, was tested in the plateau zone only $[14,39]$. Clearings show thin OL and OF horizons, no white rot in the litter, and a thin, light-coloured A horizon. The phase of intense growth and competition is characterized by thick OL and OF horizons, a thicker A horizon (coloured at the surface and clear at the base) and, at times, an $\mathrm{OH}$ horizon; altogether, these features indicate an accumulation of organic matter at the surface of the soil and a slow decomposition of litter. The mature phase is characterized by the presence of thin OL and OF horizons and a thick uniformly-coloured A horizon, thus meaning a better incorporation of organic matter. The passage to the thin lightcoloured A horizon observed in clearings can be explained by a probable increase in the mineralization rate of organic matter in the A horizon, which is concomitant with a decrease in organic matter input and higher temperature maxima and water content in the top horizons [43]; increased leaching might be expected too in relation to an increase in incident rain and a fall in the activity of soil-dwelling earthworm species.

Similar observations have been made in mountain spruce forests, at the upper montane level, with still more pronounced changes in humus forms during sylvigenesis [8, 40, 41].

\section{FOREST DYNAMICS AND NEMATODE FAUNA}

\subsection{Changes in trophic groups}

To clarify the influence of humus forms [2], thirteen sites only in the 'plateau' zone with an acid mull humus were analysed and grouped according to their age and successional stage [1,3]. Investigations on 39 samples at two seasons of the year, supported by correspondence analysis, revealed a cyclic change in the trophic structure of nematode communities in relation to forest dynamics [1]. To make easier the understanding of results, 'clearing' as a whole included a clearing developed in a senescent stage and a clearing opened up in a mature stage approximately 100 years old (late pole stage) with different patches of herbaceous vegetation; late pole stage and senescent stage 
were grouped under 'mature' stage as a whole and the 'growth' stage included sites of different areas. Comparing the relative abundance of trophic groups at the different sites (figure 4), the authors showed that bacterial feedingnematodes $(38.05 \%)$ and predators $(1.43 \%)$ were most important in clearings compared to other stages, thus indicating temporary trophic changes taking place in such an environment, as seen above, perhaps due to an increase in mineralization rates. This temporary phenomenon has also been observed in experiments involving suppression of litter inputs $[4,6]$, or clear-cutting $[22,49,50]$. In clearings or after clear-cutting, microclimate conditions changed and large variations in energy input to the soil influenced microbial production and nematodes, especially bacterialfeeding nematodes, as it was reported by Baath [7], Lundgren [32] or Sohlenius [50]. The growth phase was characterized by the most important population of fungal-feeders (27.77\%), thus indicating accumulation of litter with a dominance of fungal decomposition, associated with acidification of the environment $[6,47]$. The dominance of fungal-feeding species was even higher when the surface area of the eco-units was larger. Lastly, mature stands and, moreover, sites in which senescence of beech was prevailing in comparison to the late pole stage, were characterized by the highest abundance of phytoparasites $(20.44 \%)$ and omnivores $(8.16 \%)$. Similar changes in nematode populations have already been observed in very old oak or Scats pine stands [33, 53], and De Goede et al. [13] reported similar progressive changes in trophic groups during colonization of dunes by vegetation. The amount of omnivores was associated with a relatively stable environment [35], a decrease in the abundance of these animals, or their disappearance, can be interpreted as an indicator of environmental disturbance [21, 54]. Nevertheless, an opening occurring when trees are senescent causes less disturbance, which could explain that no decrease, at least at the beginning of gap opening, was observed in omnivorous nematodes in the herbaceous clearing located in the senescent stage contrary to the clearing located in a late pole stage (bare or herbaceous clearing) as shown in figure 4. We will consider this point again in the following paragraph. It is also worthy to note that vertical and horizontal heterogeneities according to the development of herbaceous vegetation were clearly shown from correspondence analysis results [I, 31 and this gives much stronger weight to the results because the whole nematofauna reacted to vegetation.

\subsection{The importance of clearings}

Changes in nematode communities within the same sylvigenetic phase have been observed [1]. The comparison of 
two types of clearings, one in a late pole stage (with two sampling zones, bare ground and herbaceous cover made of Melica uniflora Retz.), the other in a senescent stand (with herbaceous cover of Brachypodium sylvaticum Beauv. and Festuca heterophylla L.) showed that the nematode communities within the clearings strongly resembled those in nearby forest stands. In particular, the clearing in the senescent area was characterized by the weak relative den sity of the acidophilic species Tylolaimophorus typicus (de Man 1880) and the strong relative density of phytoparasites and omnivores, under the trees still in the senescent phase (figure 4). By observing the densities of Mononchida predators, which are good indicators of humus types [2], in particular the variation in the relative abundance of species and the morphometric variability of the ubiquitous species Clarkus papillatus (Bastian 1865) Jairajpuri 1970 [5], it was possible not only to confirm the above observations but also to provide additional information [3]. Significant differences were supported according to the results of a correspondence analysis and measurements of $C$. papillatus (means with confidence intervals). Thus, a scaling of sites was observed: the bare clearing in the late pole stage, the growth stage and the late pole stage were the more acidic sites; they were characterized by bigger-sized animals (body length and width, buccal cavity length and width). The clearing opened in the senescent area, the senescent sites and the herbaceous zone with Melica uniflora, were characterized by smaller-sized animals, the morphometric characters of which resembled those of animals collected in alkaline environments [2, 5]. In fact, the senescent site and thecontiguous clearing showed an intense burrowing activity of earthworms and moles and a deposition of limestone gravel close to the surface, which was not the case in the other clearing. Moreover, acidic sites, particularly the bare clearing, showed a strong relative abundance of acidophilic species (such as $C$. papillatus, from 70 to $97 \%$ ) while the senescent sites and the contiguous clearing showed a decrease in the abundance of $C$. papillatus (from 65 to $22 \%$ ), a correlative increase in the densities of neutrophilic species (such as Prionchulus muscorum (Dujardin (1845) Wu and Hoepli 1929) and the presence (from 3 to $36 \%$ ) of two species normally present in calcic environmental conditions (Coomansus parvus (de Man 1880) Jairajpuri and Khan 1977 and Mylonchulus brachyuris (Buetschli 1873) Altherr 1953). Analyses of the total nematofauna [1] showed a differentiation of these sites but did not distinguish a characteristic change of humus.

Such changes in the nematode fauna emphasize two points. First, clearings appear as a zone of disruption of the ecosystem, which can evolve differently according to the place where this disruption occurs: a storm does not have the same impact on humus profiles and thus on the regeneration process (beech regeneration is greatly dependent on humus quality $[31,37,38,55]$ when wind-throw occurs in young or in senescent stands. Second, under 
the soil conditions of the present study, the heterogeneity resulting from natural forest dynamics is reflected in changes in the nematode fauna and could be interpreted as the existence in the soil of cyclic processes in the continuity of time, which in turn generate heterogeneity and, therefore, diversity.

\section{EMERGENT CONCEPTS AND CONCLUSIONS}

The functional processes taking place inside the forest ecosystem can be appreciated, as well from the point of view of fundamental ecology as of that of the forest expert, if they are studied complementarily under various aspects. Mathieu et al. [34] had already emphasized this fact by studying some sites in the Belgian Ardennes which were not strongly modified by human activities and where current soil hydrodynamics could not be appreciated by morphological diagnoses only, because discordances appeared between the pedological profiles and the diversity of the phytosociological communities and humus. In the present paper, we tried to emphasize different functional approaches, notably the contribution of soil biology, by combining geomorphological and humus features, forest dynamics and fauna behaviour.

Lemée et al. [30] emphasized the existence of two evolutions in the ecosystem dynamics of biological reserves of the Fontainebleau forest. First, the observation of pollen profiles and the datation of charcoal carbon showed a linear evolution in relation to climate changes, with the replacement, within mixed oak stands (Quercus petraea Liebl.), of hazel (Corylus avellana L.) under Atlantic climate by lime (Tilia platyphyllos Stop.) under boreal climate and then by pure oak which was progressively substituted by beech (Fagus sylvatica L.) under the present sub-Atlantic climate. Second, a cyclic evolution was represented by a mosaic of eco-units of varying size which evolve in space and time and where gaps, most often caused by storms, are the driving force in sylvigenesis as well as a source of plant biodiversity.

We previously emphasized this dynamic process by considering the evolution of the relative area occupied by clearings over time. Gap opening, showed also its influence on the phytosociological biodiversity; in adding it to the three basic phytosociological groups related to the pedological types and corresponding to the particular geomorphology of 'La Tillaie', not only a diversification of the herbaceous layer but also a development of social heliophytes and shade-intolerant trees, which are able to delay more or less durably the regeneration process of 
beech, appear. It is the case for Calamagrostis epigeios or Pteridium aquilinum particularly in the largest clearings on sandstone.

The study of humus forms first revealed a distribution according to the three geomorphological situations. However, a discordance appeared in the sandhill zone where, in spite of the podsol soil type we can note the existence of a mull-moder humus. Mathieu et al. [34] had also emphasized that humus profiles were superimposed to pedological profiles and, thus, humus forms, according to phytosociological communities, reflected a steady state soil/vegetation at a given time and the current dynamics of the profile. The study of the soil fauna at 'La Tillaie', particularly Lumbricidae, brings an additional element to the understanding of the formation of the humus profile by linking the presence of limestone, the distribution and activities of ecological categories of Lumbricidae.

While gaps remain a random sudden event, the renewal of the ecosystem is also associated with soil biological processes which are continuous in time, linking life stages of trees, humus forms and animal populations. Macromorphological features of humus profiles changed along with the forest dynamics. Moreover, concomitant changes within functional groups of animals give even more strength to this observation. Particularly, the natural process of acidification and accumulation of organic matter observed during the growth phase cannot be compared to field manipulations, such as acid input $[23,45,47]$ or increased litter supply $[6,12]$. In both cases, the relative abundance of fungal-feeding nematodes increases, but the density of the total nematode population decreases in experimental treatments while it reaches a maximum during the growth phase and then fits in the natural process of forest dynamics. The dominance of each trophic group reflects particular modifications of the ecosystem and seems to follow a cyclic evolution. In addition, the decrease in relative abundance and density of plant-feeding nematodes during the passage from the senescent phase to the gap opening cannot be compared to the increase observed after experimental deprivation of litter, simulating an effect of gap opening $[4,6]$. In this last case, the authors concluded that in experimental treatments, withholding of litter illustrated a temporary process linked to the importance of roots and rhizosphere marked by the reaction of plant-feeding nematodes which invade rootlets of trees and herbs during a few years. In contrast, in biological reserves, changes in animal communities and humus forms are more continuous in time, being observed during the development of beech stands, from establishment to senescence of trees. However, this last point deserves further investigations into causal relationships.

Thus, two important functional concepts emerge from these recent works in ecology and soil biology in 
natural forests. One is the discovery of a parallelism between the natural forest cycle and an edaphic cycle linking animal populations and humus forms (figure 5). When these two cycles start from a gap affecting a senescent ecounit, they proceed in a co-ordinated way: at a given time, humus forms, vegetation and functional groups of animals are in phase. It is the case in the mature phase and then in the senescent phase where the progressive development of a mull, favourable to the regeneration of beech, was characterized by the activity of burrowing fauna (endogeic and anecic Lumbricidae) and a dominance of the phytoparasitic and especially omnivorous nematodes. It is also the case in the growth phase where an accumulation of organic matter and an acidification of the environment is emphasized by a dominance of epigeic Lumbricidae and fungal-feeding nematodes. This supposes a co-adaptation between the sylvigenetic cycle and the edaphic cycle.

Anyhow, a tree-fall gap remains a random sudden event of variable amplitude. It is more likely to occur when an eco-unit has reached the senescent phase, but it may intervene before as well. In this case, sylvigenetic and edaphic cycles disagree, which may alter the fate of the eco-unit. This is the second important concept. It is particularly the case of the clearing located in the mature phase. We noted differences in the nematode populations when we compared two clearings, one close to a late pole stage and the other in the middle of a senescent phase. In the first case, the relative abundance of both omnivorous nematodes and Tylolaimophorus typicus showed a disruption in the normal process of forest dynamics. If this appears as an additional factor of amplification in the expansion of plant ecological diversity, because of a diversification of trajectories followed by eco-units, it causes also a risk of disruption and fragility of the ecosystem. This point deserves further consideration from the point of view of fundamental ecology and also for forestry management which aims at programming trajectories favourable to the sustainable conservation of biodiversity. Notably, we observed that the size of eco-units was of paramount importance for the sustainability of forest ecosystems, mainly through regeneration processes, which are strongly substrate-dependent $[31,37,38,41,55]$. In natural forests, organisms rapidly invade the future regeneration sites once conditions become favourable, as this is the case during mature stages. In managed forests, especially in evenaged stands, these processes are impeded, free colonization from the vicinity by potential soil improvers being slow or even impossible. Thus in most managed forests, regeneration must be artificial, by planting and fertilizing the sites.

Generally, these results illustrate the interest of studies carried out on biological reserves and emphasize the necessity of complementary research and notably the contribution of soil biology to a functional approach of forest 
ecosystem.

\section{REFERENCES}

[1] Armendáriz I., Arpin P., Nematodes and their relationship to forest dynamics: I. Species and trophic groups, Biol. Fertil. Soils 23 (1996) 405-413.

[2] Arpin P., Mise au point sur la caractérisation biologique des humus forestiers par l'étude des nématodes Mononchida, Rev. Ecol. Biol. Sol. 28 (1991) 133-144.

[3] Arpin P., Armendáriz I., Nematodes and their relationship to forest dynamics: II. Abundance and morphometric variability of Mononchida related to changes in humus forms, Biol. Fertil. Soils 23 (1996) 414-419.

[4] Arpin P., Ponge J.-F., Vannier G., Verdier B., Réactions des populations animales et microbiennes du sol à la privation des apports annuels de litière : exemple d'une rendzine forestière, Bull. Ecol. 16 (1985) 95-115.

[5] Arpin P., Jagers op Akkerhuis G., Ponge J.-F., Morphometric variability in Clarkus papillatus (Bastian, 1865) Jairajpuri 1970 in relation to humus type and season, Rev. Nematol. 11 (1988) 149-158.

[6] Arpin P., Ponge J.-F., Vannier G., Experimental modifications of litter supplies in a forest mull and reaction of the nematode fauna, Fundam. Appl. Nematol. 18 (1995) 371-389.

[7] Baath E., Soil fungal biomass after clear-cutting of a pine forest in Central Sweden, Soil Biol. Biochem. 12 (1980) 495-500.

[8] Bernier N., Ponge J.-F., Humus form dynamics during the sylvogenetic cycle in a mountain spruce forest, Soil Biol. Biochem. 26 (1994) 183-290.

[9] Blandin P., Luce J.-M., La surveillance des systèmes écologiques et de la biodiversité, problèmes conceptuels et méthodologiques, Bull. Sot. Entomol. France 99 (1994) 39-54.

[10] Bouchon J., Faille A., Lemée G., Robin A.-M., Schmitt A., Cartes et notices des sols, du peuplement 
forestier et des groupements végétaux de la réserve biologique de «La Tillaie » en forêt de Fontainebleau, université d'Orsay, France, 1973, 12 p. +3 cartes hors-texte.

[11] Carbiener R., Les écosystèmes forestiers. Aspects fonctionnels liés à l'évolution biogéographique et aux influences anthropiques, Colloq. Phytosociol. 20 (1991) 73-99.

[12] David J.-F., Ponge J.-F., Arpin P., Vannier G., Reactions of the macrofauna of a forest mull to experimental per- turbations of litter supply, Oikos 61 (1991) 316326.

[13] De Goede R.G.M., Verschoor B.C., Georgieva S.S., Nematode distribution, trophic structure and biomass in a primary succession of blown-out areas in a drift sand landscape, Fundam. Appl. Nematol. 16 (1993) 525538.

[14] Delhaye L., Ponge J.-F., Etude des peuplements lombriciens et des caractères morphologiques des humus dans la réserve biologique de «La Tillaie » (Forêt domaniale de Fontainebleau, Ile-de-France), Bull. Ecol. 24 (1993) 41-51.

[15] Denisot G., Carte géologique détaillée de la France au 1/50 $000^{\mathrm{e}}$ : Feuille de Fontainebleau et notice explicative, BRGM, Orléans, 1970, 20 p. + 1 carte hors-texte.

[16] Driessen P.M., Dudal R., The major soils of the world, Agricultural University of Wageningen and Catholic University of Leuven, 1991.

[17] Faille A., Influence sur la végétation herbacée de l'ouverture de trouées dans les réserves biologiques de la forêt de Fontainebleau, Bull. Ecol. 11 (1980) 1-10.

[18] Faille A., Lemée G., Pontailler J.-Y., Dynamique des clairières d'une forêt inexploitée (réserves biologiques de la forêt de Fontainebleau). II-Fermeture des clairières actuelles, Acta Oecol. Oecol. Gener. 5 (1984) 181189.

[19] Falinski J.B., Succession, regeneration and fluctuation in the Bialowieza Forest (NE Poland), Vegetatio 77 (1988) 115-128.

[20] Falinski J.B., Mortier F., Biodiversité et gestion durable des forêts, Rev. For. Fr. 48 (1996) 89-116. 
[21] Freckman D.W., Ettema C.H., Assessing nematode communities in agroecosystems of varying human intervention, Agric. Ecosyst. Environ. 45 (1993) 239-261.

[22] Huhta V., Karppinen P, Nurminen M., Valpas A., Effect of silvicultural practices upon arthropod, annelid and nematode populations in coniferous forest soil, Ann. Zool. Fenn. 4 (1967) 87-143.

[23] Hyvonen R., Persson T., Effects of acidification and liming on feeding groups of nematodes in coniferous soils, Biol. Fertil. Soils 9 (1990) 205-210.

[24] Koop H., Forest Dynamics, Springer-Verlag, Berlin, 1989.

[25] Lemée G., Sur l'intérêt écologique des réserves biologiques de la forêt de Fontainebleau, Bull. Sot. Bot. Fr. 113 (1966) 305-323.

[26] Lemée G., Investigation sur la minéralisation de l'azote et son évolution annuelle dans des humus forestiers in situ, Oecol. Plant. 2 (1967) 285-324.

[27] Lemée G., La hêtraie naturelle de Fontainebleau, in: Lamotte M., Bourlière F. (Eds.), Problèmes d'écologie: structure et fonctionnement des écosystèmes terrestres, Masson, Paris, 1978, pp.75-128.

[28] Lemée G., Rôle des arbres intoléants à l'ombrage dans la dynamique d'une hêtraie naturelle (Forêt de Fontainebleau), Acta Oecol. Oecol. Plant. 6 (1985) 3-20.

[29] Lemée G., Les réserves biologiques de «La Tillaie » et du « Gros Fouteau » en forêt de Fontainebleau, écocomplexes climaciques, Bull. Sot. Bot. Fr. 137 (1990) 47-62.

[30] Lemée G., Faille A., Pontailler J.-Y., Dynamique linéaire et cyclique d'une forêt inexploitée: cas des réserves biologiques de la forêt de Fontainebleau, Colloq. Phytosociol. 20 (199 1) 273-282.

[31] Le Tacon F., Oswald H., Influence des facteurs édaphiques sur l'abondance des fructifications, in: Teissier du Cros E. (Ed.), Le hêtre, Inra, Paris, 1981, pp. 216-291.

[32] Lundgren B., Bacteria in a pine forest soil as affected by clear-cutting, Biol. Biochem. 14 (537-542).

[33] Magnusson C., Abundance and trophic structure of pine forest nematodes in relation to soil layers and 
ground cover, Hol. Ecol. 6 (1983) 175-182.

[34] Mathieu L., van Praag H.J., Weissen F., Delecour F., Sougnez N., Etude intégrée des sols a pseudo-gley sous végétation naturelle du plateau des Hautes Fagnes (Belgique), Partie I : le milieu de pédogenèse, la morphologie et le fonctionnement actuel des profils, Catena 8 (1981) 299-323.

[35] Niblack T.C., Bernard EC., Nematode communitiy structure in dogwood, maple and peach nurseries in Tennessee, J. Nematol. 17 (1985) 126-131.

[36] Oldeman R.A.A, Forest: Elements of Silvology, Springer-Verlag, Berlin, 1990.

[37] Page G., Some effects of conifer crops on soil properties, Common For. Rev. 47 (1968) 52-62.

[38] Page G., Effects of forest cover on the properties of some Newfoundland forest soils, Canadian Forestry Service, Department of the Environment, Ottawa, Publication No. 1332, 1974.

[39] Ponge J.-F., Delhaye L., The heterogeneity of humus profiles and earthworm communities in a virgin beech forest, Biol. Fertil. Soils 20 (1995) 24-32.

[40] Ponge J.-F, André J., Bernier N., Gallet C., La régénération naturelle: connaissances actuelles. Le cas de l'épicéa en forêt de Macot (Savoie), Rev. For. Fr. 46 (1994) 25-45.

[41] Ponge J.-F, André J., Zackrisson O., Bernier N., Nilsson M.C., Gallet C., The forest regeneration puzzle: biological mechanisms in humus layer and forest vegetation dynamics, Bioscience 48 (1998) 523-530.

[42] Ponge J.-F., Patzel N., Delhaye L., Devigne E., Lévieux C., Béros P., Wittebroodt R., Interactions between earthworms, litter and trees in an old-growth beech forest, Biol. Fertil. Soils (1999) (in press).

[43] Pontailler J.-Y., La régénération du hêtre en forêt de Fontainebleau: ses relations avec les conditions hydriques stationnelles, Ph.D. thesis, université d’Orsay,France, 1979.

[44] Pontailler J.-Y., Faille A., Lemée G., Storms drive succession dynamics in natural forests: case study in Fontainebleau forest (France), For. Ecol. Manag. 98 (1997) 1-15.

[45] Ratajczak L., Funke W., Zell H., Die Nematoden eines Fichtenforstes, Auswirkungen anthropogener 
Einflusse, Verh. Ges. Gkol. 17 (1989) 391-396.

[46] Remmert H., The Mosaic-Cycle Concept of Ecosystems, Springer-Verlag, Berlin, 1991.

[47] Ruess L., Funke W., Effects of experimental acidification on nematode populations in soil cultures, Pedobiologia 36 (1992) 23 1-239.

[48] Schtitz J.-Ph., Oldeman R.A.A., Gestion durable par automation biologique des forêts, Rev. For. Fr. 48 (1996) 65-74.

[49] Sohlenius B., Short-term influence of clear cutting on abundance of soil microfauna (Nematoda, Rotatoria and Tardigrada) in a Swedish pine forest soil, J. Appl. Ecol. 19 (1982) 349-359.

[50] Sohlenius B., Structure and composition of the nematode fauna in pine forest soil under the influence of clear-cutting. Effects of slash removal and field layer vegetation, Eur; J. Soil Biol. 32 (1996) 1-14.

[51] Topoliantz S., Étude de la régénération du hêtre en forêt de Fontainebleau: faînée de 1996, survie et distribution des plantules de première année dans la réserve biologique de «La Tillaie », Mémoire de maitrise de biologie des populations et des écosystèmes, université Paris-VI, 1997.

[52] Walter J.-M.N., Bref aperçu du statut et de la dynamique des forêts anciennes naturelles et semi-naturelles d'Europe, Rev. For. Fr. 43 (1991) 173-184.

[53] Wasilewska L., Nematodes of the dunes in the Kampinos Forest. II. Community structure based on numbers of individuals, state of biomass and respiratory metabolism, Ekol. Polska 19 (197 1) 651-688.

[54] Wasilewska L., The structure and function of soil nematode community in natural and agrocenoses, Pol. Ecol. Stud. 5 (1979) 97-145.

[55] Weissen F., Problèmes de régénération en hêtraie ardennaise, Bull. Soc. Roy. Forest. Belgique 93 (1986) 113-117. 


\section{Legends of figures}

Figure 1. Evolution of the relative area occupied by gaps ( — total area; --- area from 1967 storm only), modified from Pontailler [44].

Figure 2. Mortality rate of 1-year-old beech seedlings due to dryness in relation to geomorphological features in ' $\mathrm{La}$ Tillaie' (letters indicate homogeneous groups, effects were analysed separately by $t$-tests).

Figure 3. Changes in densities of earthworm ecological categories according to forest dynamics in the 'plateau' zone in 'La Tillaie'.

Figure 4. Relative abundances of the main trophic groups of nematodes according to forest dynamics in the plateau zone in 'La Tillaie', modified from Armendáriz and Arpin [1]. ( $\rightarrow$ phases of the sylvigenetic cycle, ---> changes in the same phase).

Figure 5. Relationships between the sylvigenetic cycle and the edaphic cycle (humus forms and soil animal communities) in 'La Tillaie'. (BE, FE, PF., PRED., OMN., bacterial-, fungal-, and plant-feeders, predators and omnivores nematode trophic groups, respectively; ANEC., END., EPLL., anecic, endogeic and epigeic earthworm species, respectively). 


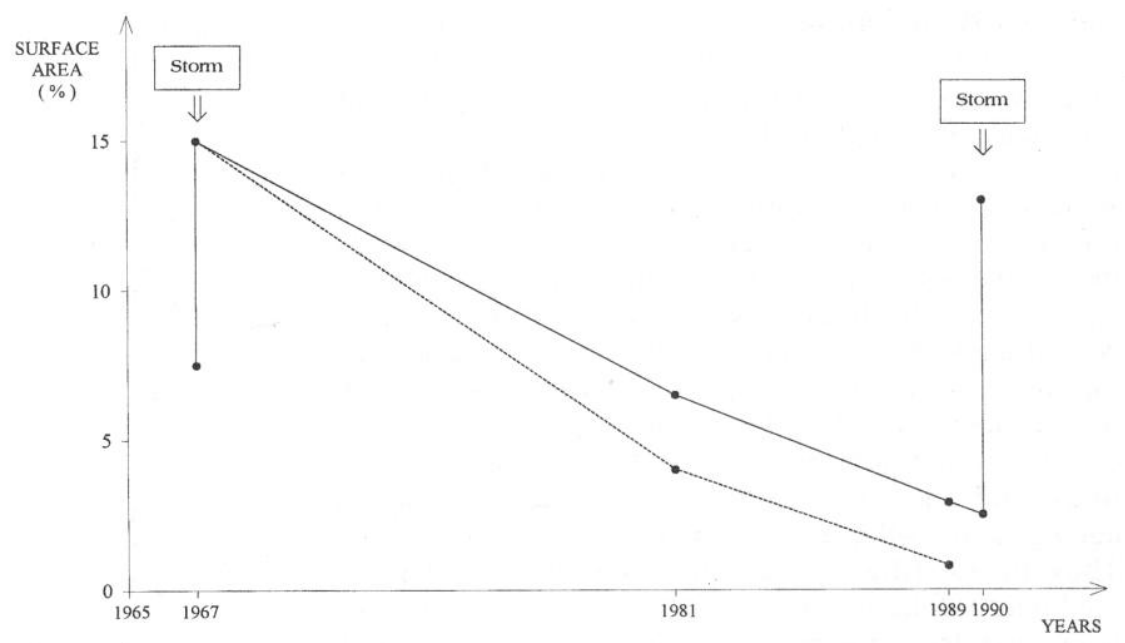

Fig. 1 


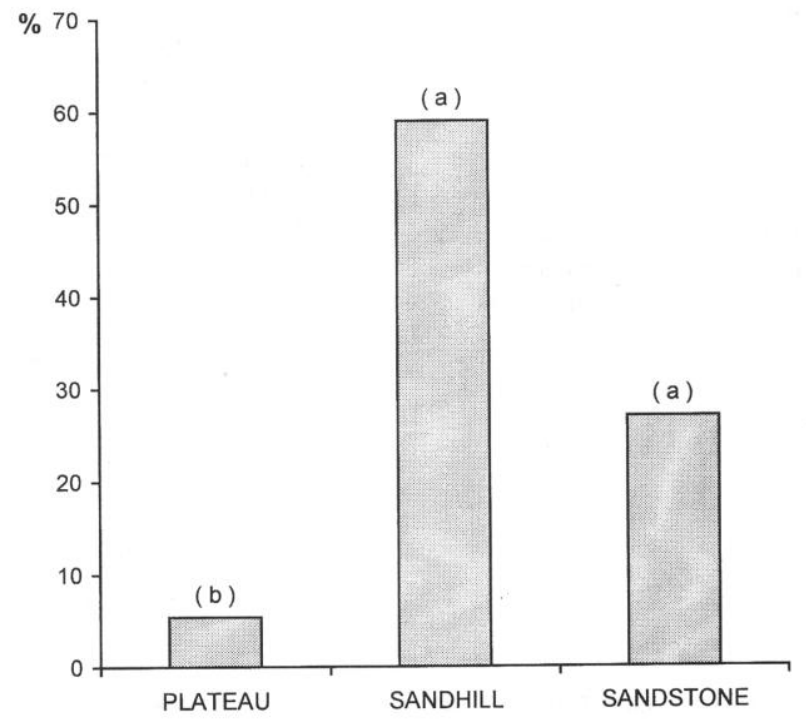

Fig. 2 
Mean number of individuals $/ \mathrm{m}^{2}$

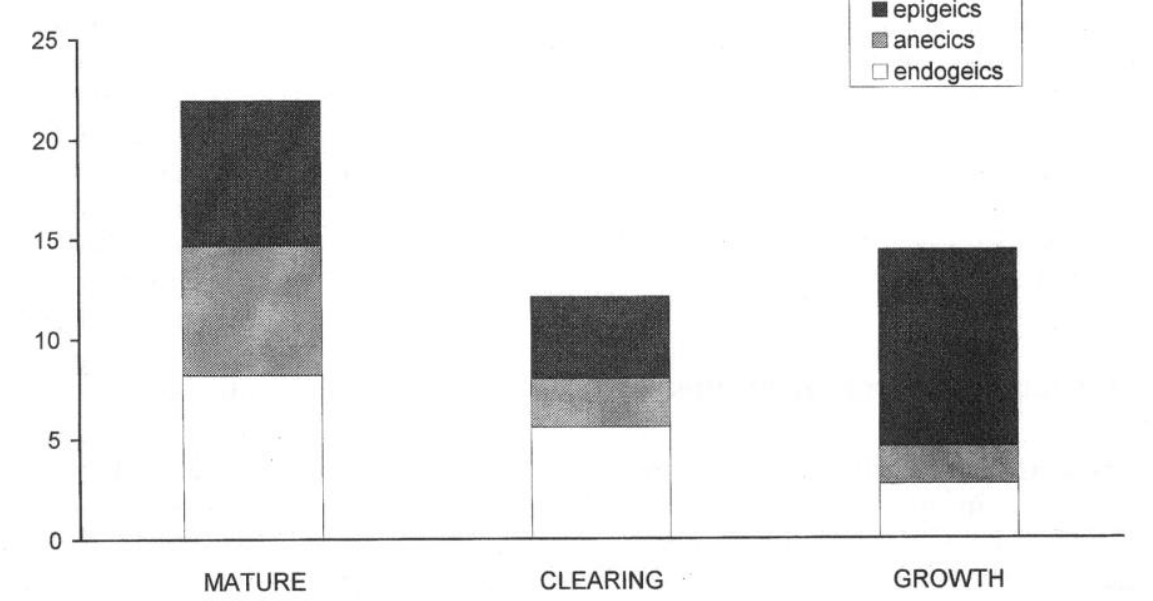

Fig. 3 


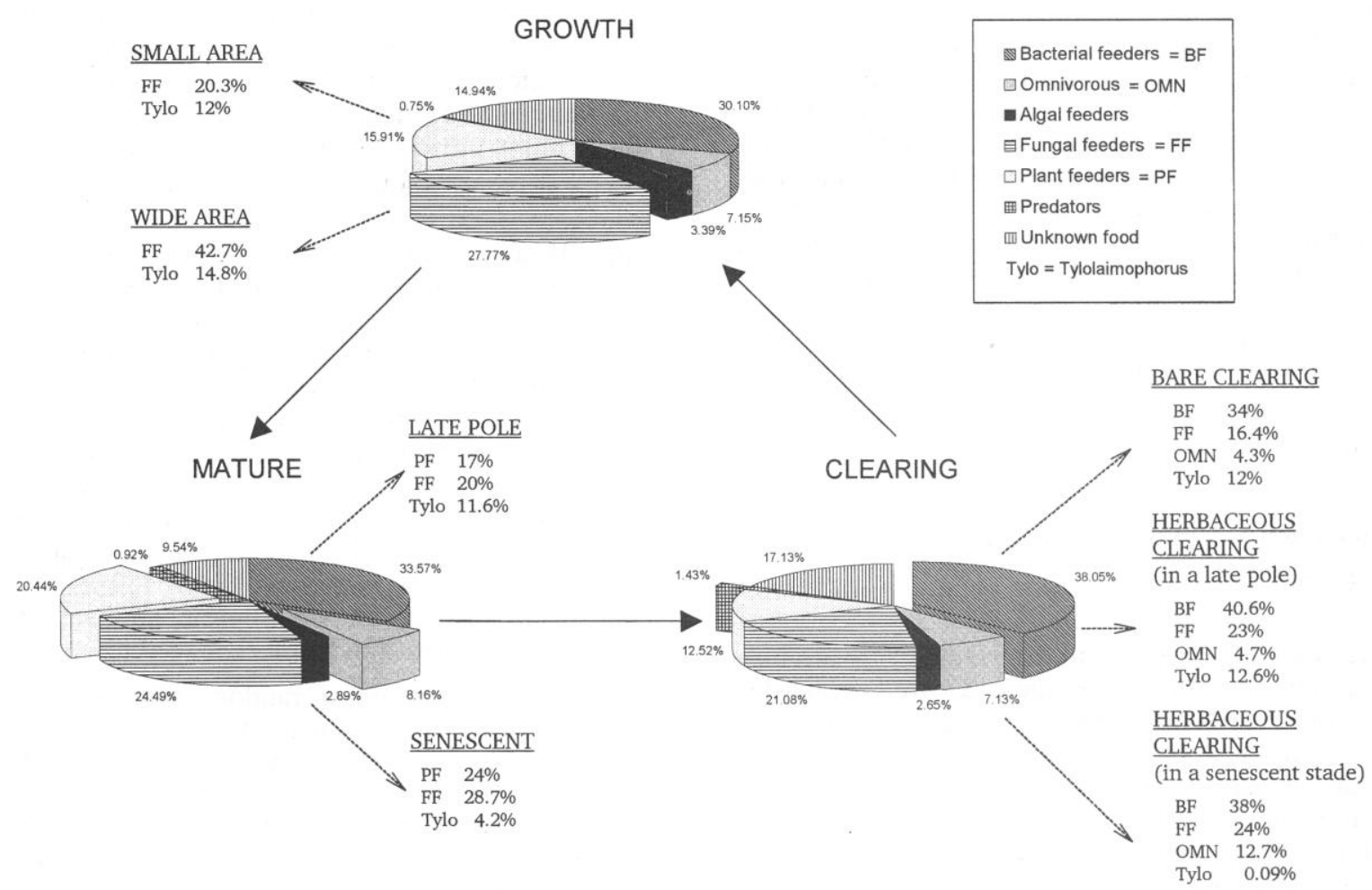

Fig. 4 


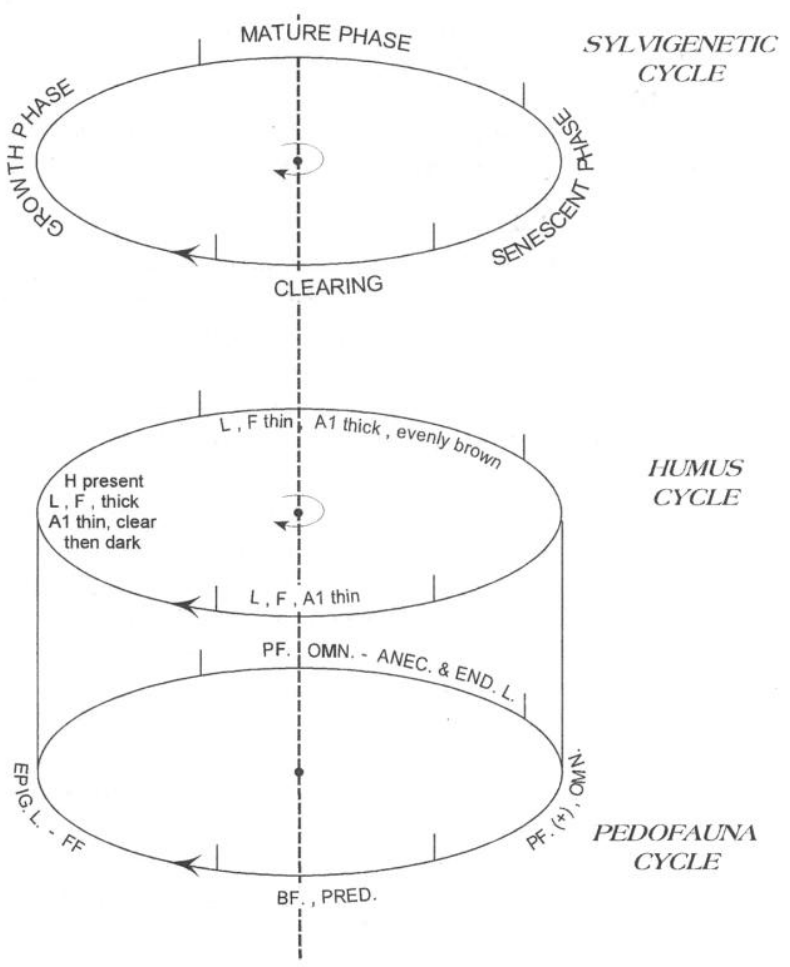

Fig. 5 